\title{
Addiction of Information and Communication Technology (ICT) and Internet by the Bangladeshi University Students and Its Impact on Their Future
}

\author{
Md. Mahbobor Rahaman \\ Lecturer (MIS), Dept. of Business Administration, Leading University, Ragib Nagor, Kamal Bazar, \\ South Surma, Sylhet, Bangladesh \\ E-mail: mahbobdumis@gmail.com, Cell: +8801723347110
}

Received: 06 May 2018; Accepted: 07 July 2018; Published: 08 August 2018

\begin{abstract}
The world is going to be a universal digital village and from the flow of this digitalization Bangladesh also riding of the tide. The key points of these digitalization is young generations basically university students of Bangladesh. ICT and Internet is a new trend for this country that's the main reasons to encompass this by opportunity by young students. Bangladeshi young generations have also addicted in the upper tier of this list. The addiction of ICT \& internet is more on the young generations than any other parts of the people generally in the third world countries. The main objective of this paper is to investigate the excessive use of Information and Communication Technology (ICT) and internet by the university students in Bangladesh. The study had collected the data from 24 public and private universities in Bangladesh out of 135. The study was used the simple random sampling (SRS) for analyzing the sample size with IBM SPSS 23.
\end{abstract}

Index Terms-ICT, Internet Addiction, Bangladesh, University, Students, Future Impact.

\section{INTRODUCTION}

Information and Communication Technologies (ICT) has becoming the most talk able topics of the recent years not only in the developed countries but also in the developing and underdeveloped countries(Balfour \& Allen, 2014). This buzz word has introduced as a newest form in communication in Bangladesh. The literacy of ICT was not properly introduced in Bangladesh and has a high impact on their future life(Art, n.d,2012).

The paper was divided into two parts one is for the introduction about the use of internet and ICT by the university students in Bangladesh and other is for the addiction and its effects on their future. The analysis part was analyzed according to the divisions and category of public and private universities in Bangladesh. All the collected data was analyzed with the help of various statistical tools.
ICT can be powerful tool in the sector of education and not only the future of fresh graduate but also the demand for teachers to be confident and competent users of ICT for their personal and professional lives is continually growing due to rapid changes in ICT(Ismail, 2016). Addictions of technology have been an important focus of in various studies around the world (Carbonell \& Panova, 2017).The addiction of ICT(Greene, Approved, Praslova, \& Georgianna, 2016), Internet, Mobile phone, television, gamming, on line gaming and social media addiction has been revulsion in the recent decades not only around the world but also the developing countries like Bangladesh (Ejechi, 2016). The use of Internet and ICT is a good sign for any county that this country is keeping with the trends of modern technology(Rahaman, 2017). But when this usage will become an addiction it will cause a serious harm for the entire nation(Corporation, 2003). Use of the internet in an addictive mode is fast becoming a significant problem worldwide now(Claro, n.d.).

In Bangladesh university students are particularly vulnerable for the reason that the internet has already been an integral part and parcel of student life in a whole day rather than their text books and other activities (Meenakshi, 2013). Most of the university students are highly engaged in the virtual life such as ICT and internet (Derevensky \& Gilbeau, 2015). The addiction of ICT and Internet by the university students all around the world is potentials amount and which have an empirical evidence (e.g., Amichai-Hamburger \& Ben-Artzi, 2003; Amiel \& Sargent, 2004; Kim, LaRose, \& Peng, 2009 ; Balakrishnan \& Shamin, 2013; Haghighi, Othman, \& Hashim, 2011; Che Su, Noor, \& Awanis, 2012; Ng, Saramah, Aili, Subash, \& Kaur, 2012; Nurhilyana, Zaid, \& Aminatul, 2013; Soh, Teh, Hong, Ong, \& Charlton, 2013).The maximum studies in Bangladesh found that they were trying to identify the potentialities and positive effects of ICT and Internet on the life on university students (Yildirim, 2014). Though, some of the studies have investigated the negative impact of Internet and ICT on students in various level of the education (Talukder, 
Alam, \& Apu, n.d.)which was so limited (Muduli, 2013). Bangladesh is developing countries, all aspects of this country is developing gradually including technology(Dorji, 2015), ICT and computer technology etc. (Youssef \& Dahmani, 2008).

\section{RELATED WORKS}

ICT is one of the most important driving forces promoting economic growth and sustainability of any country(Islam, 2016). The last few years Bangladesh has invested heavily in ICT (Rahaman, 2017b). Moreover, the use of ICT in education and training has been a key priority in Bangladesh(Rahaman \& Akter, 2017). ICT has had a major impact on the education sectors on organization and on teaching and learning methods (Bahrainian \& Khazaee, 2014) .ICT can be a helpful tool in all aspects with the help of various applications for distance education (Sharma, P. ,2014), Facebook groups (Wang, 2011), Google plus groups (Sussman, OMAR, BOLONG, \& OSMAN, 2011), various social groups (Schuemann, 2014), newspapers, the internet, radio, televisions etc. (Islam, 2016) .Most of the academic institutions are rapidly adopting ICTs (Mbah, 2010) which has gone a long way in facilitating the provision of internet services to students and university staffs (Islam, N., Khudri, M. M., \& Afrin, S. ,2017 ; Waithaka, 2013).

Most of the researchers and academicians have been debating about the students' academic performance being influenced both positively and negatively with the increasing internet users (Englander, Terregrossa, \& Wang, 2010). It was shows that the number of students accessing internet multiplies every year in Bangladesh (Haque, H. J., \& Shahriar, F. M.,2015). Some of the researchers indicated that the student's access on the internet for academic purposes student's academic performance will be enhanced in most of the cases (Brown, Ellore \& Niranjan, 2014). ICT has a key role in the development of the student's performance if they can use it on the right track (Teong \& Ang, 2016). Many benefits are associated with Internet and use of ICT (Karamti, C., 2016), such as access to needed information or desired information, easy access to news, easy to get the study related information and interpersonal communication with all others friends and faculties (Nketiah-Amponsah, E., Asamoah, M. K., Allassani, W., \& Aziale, L. K. ,2017)..

However, in addition with the phenomenal growth of the Internet(Wilkins, n.d.), ICT and its various use (Oduma, n.d.), there has been a growing concern worldwide regarding the risks associated with ICT by the use of university students(Mai \& Wanajak, 2011).A study from Kenya found that Google and Yahoo were the most commonly used search engines and study also led to the conclusion that university students use the internet for various reasons that including research works (Omiunu, 2017), academic activities (Opira Geoffrey, 2014), communication and social activities (Waithaka, 2013).In their study they identified the potential advantages of internet and ICT for the university graduate students(Ngoumandjoka, 2012 ; North,Johnston, \& Ophoff, 2014).

It was also believed that there could be widespread addiction of ICT and Internet(Lorencowicz, Kocira, Uziak, \& Tarasińska, 2014) in particularly amongst college and university students (Chou \& Hsiao, 2000; Fortson, Scotti, Chen, Malone, \& Del Ben, 2007; Kim, et al., 2010; Kubey, Lavin, \& Barrows, 2001; Morahan Martin \& Schumacher, 2000).Now days psychology has collected convincing data showing that the students will be more attractive in the use of ICT and Internet for their personal and educational purpose in various way (UNESCO, 2004).

Addiction of ICT all over the world is almost same in a specific age of people (Casey, 2012). A report from the Australia that $90 \%$ of 16 to 29 years old people were using the internet daily and they spend on an average of 22 hours per week than any other age group(Collin, Rahilly, Richardson, \& Third, 2011). There were some benefits from the addiction of ICT of young people generally the university graduates. There have a positive impact on education by the ICT in all aspects of students(Eke Miss, Omekwu Prof, \& Odoh Miss, 2014). The students from rural and urban areas will be in an equal platform by the use of ICT and computer technology (Rahaman \& Akter, 2017). ICT can have a great impact on their students life as well as their future (Nath, Chen, Muyingi, \& Lubega, 2013). The use of Internet and ICT among young people (M Shahriar, F., Haque, J., \& Barai, M. K. , 2016 ), those who studying in the university levels, is considerably higher than other age groups in not only in Bangladesh but also in the undeveloped countries (Nath et al., 2013).In some articles Internet addiction is shown to be positively associated with their propensity to engage in inside of the class and outside of the class ( Aristovnik, 2012 ; Jones, 2014 ).

\section{OBJECTIVES OF THE STUdY}

\section{A. Broad Objective}

The broad objective of the study is to find out the addiction of Internet and Computer related technology or ICT by the university students of Bangladesh.

\section{B. Specific Objectives}

There are some other specific objectives-

i. To identify the addiction rate of Internet and Computer related technology or ICT by the university students in Bangladesh.

ii. To explore the future impact of ICT or Computer or Internet addiction by the university students in Bangladesh. 


\section{DESCRIPTION OF METHODOLOGY}

\section{A. Survey Area}

This study will be conducted in various privates and public universities which is located in Dhaka, Chittagong, Sylhet, Rajshahi, Mymenshing and Khulna divisions (the largest tier of administration of Bangladesh) for collecting the data to analysis the addiction of ICT and its impact on their future. 100 private and 36 public universities are till now giving the services of higher education in Bangladesh. Moreover, there were 33 institutions which have been providing higher education in Bangladesh beside public and private universities. In this study five top most divisions of Bangladesh were selected for collecting primary data regarding the addiction of ICT and its impact on their life.

\section{B. Data Collection Procedures}

The data regarding the addiction of ICT will be collected from the highly educated persons from the various public and private universities or institutions by using the structured questionnaire. All the data will be collected in a closed ended and structured questionnaire method to meet the objectives of this study. The questionnaire includes sections on

i. Background characteristics of the respondent's e.g type of their educational institutions, age, gender, education level, region etc.

ii. Knowledge of ICT, using behavior of Internet and computer, types of Internet connections, duration of time spent in Online and off line, usage Patten of ICT devices, some information regarding their daily time schedule and the life style of young graduates etc.

iii. In this study the researchers also used some secondary data from the Bangladesh University Grand Commission(UGC), Ministry of Education (MoE), various web sites, newspapers and other education related news letters etc.to enhance research with an efficient and effective process.

\section{Sample Size and Sampling Design}

From the 40 public and 100 private universities from the Bangladesh, the researchers took randomly 24 universities as a sample size. This sample was taken from the five major cities namely Dhaka, Chittagong, Sylhet, Rajshahi and Mymenshing which were the major cities of public and private universities in Bangladesh.1 public 2 private universities from Sylhet division, 2 publics and 12 private universities from Dhaka divisions, 1 public and 3 private universities from Chittagong, 1 public and 1 private university from Rajshahi, 1 public university from Mymenshing division were selected for collecting primary data. Among the 24 public and private universities 645 respondents were selected for gathering data.

\section{Sampling Frame}

The Simple Random Sampling (SRS) was used for analysing the collected data .The sample size needed will be calculated using the following formula:

$$
\mathrm{n}=\mathrm{z}^{2}\left[P(1-P) / d^{2}\right] * \mathrm{D}_{\mathrm{eff}}
$$

Where

$\mathrm{n}=$ sample size

$z=$ two-sided normal variant at $95 \%$ confidence level (1.96)

$$
\begin{aligned}
& P=\text { indicator percentage } \\
& d=\text { precision } \\
& \mathrm{D}_{\text {eff }}=\text { design effect }
\end{aligned}
$$

To obtain data on indicators at $10 \%$ (d) precision and 95\% confidence interval, assuming a design effect of 2.08 and the most conservative estimate of indicator percentage $(\mathrm{P})(50 \%)$, the required sample size (n) 2400 will be required to get the objectives of the research. It is a statistically representative sample.

\section{E. Respondents}

The respondents were randomly selected public and private universities under graduate and post graduate students around the country.

\section{DATA ANALYSIS AND FINDINGS}

The study was collected various raw data and this data was analyzed for taking potentials decision. There were some descriptive statistics analysis were given as required as the research objectives.

From the table 1, it was shown that the number of male and female respondents were $64.2 \%$ and $35.8 \%$

\begin{tabular}{|c|c|c|c|c|c|}
\hline & & Frequency & Percent & $\begin{array}{c}\text { Valid } \\
\text { Percent }\end{array}$ & $\begin{array}{c}\text { Cumulative } \\
\text { Percent }\end{array}$ \\
\hline \multirow{3}{*}{ Valid } & Male & 414 & 64.2 & 64.2 & 64.2 \\
\hline & Female & 231 & 35.8 & 35.8 & 100.0 \\
\hline & Total & 645 & 100.0 & 100.0 & \\
\hline
\end{tabular}
respectively out of 645 respondents of various public and private universities in Bangladesh.

\begin{tabular}{|c|c|c|c|c|c|}
\hline & & Frequency & Percent & $\begin{array}{c}\text { Valid } \\
\text { Percent }\end{array}$ & $\begin{array}{c}\text { Cumulative } \\
\text { Percent }\end{array}$ \\
\hline \multirow{5}{*}{ Valid } & $18-20$ & 76 & 11.8 & 11.8 & 11.8 \\
\hline & $21-23$ & 488 & 75.7 & 75.7 & 87.4 \\
\hline & $24-26$ & 77 & 11.9 & 11.9 & 99.4 \\
\hline & $\begin{array}{l}30- \\
\text { More }\end{array}$ & 4 & .6 & .6 & 100.0 \\
\hline & Total & 645 & 100.0 & 100.0 & \\
\hline
\end{tabular}

Table 1. Gender

Table 2. Age 
From the table 2, it was shown that the $11.8 \%$ respondents were of the age between 18 to 20 years, $75.7 \%$ were of 21 to 23 years, $11.9 \%$ were between 24 to 26 years and $0.6 \%$ of were more than 30 years among the 645 respondents. That means most of them were young students from the graduate and under graduate levels.

Table 3. Subject/Department (Major Areas)

\begin{tabular}{|c|c|c|c|c|c|}
\hline & & Frequency & Percent & $\begin{array}{c}\text { Valid } \\
\text { Percent }\end{array}$ & $\begin{array}{c}\text { Cumulative } \\
\text { Percent }\end{array}$ \\
\hline \multirow{6}{*}{ Valid } & Business & 383 & 59.4 & 59.4 & 59.4 \\
\hline & $\begin{array}{l}\text { Arts/Law/ } \\
\text { Social } \\
\text { Sciences }\end{array}$ & 33 & 5.1 & 5.1 & 64.5 \\
\hline & $\begin{array}{c}\mathrm{CSE} / \mathrm{IT} / \mathrm{CE} \\
/ \mathrm{EEE}\end{array}$ & 133 & 20.6 & 20.6 & 85.1 \\
\hline & Agriculture & 20 & 3.1 & 3.1 & 88.2 \\
\hline & Others & 76 & 11.8 & 11.8 & 100.0 \\
\hline & Total & 645 & 100.0 & 100.0 & \\
\hline
\end{tabular}

From the table 3, it depicts that in case of departments or major areas $59.4 \%$ respondents were from Business areas, $5.1 \%$ were from arts, laws or social science background, $20.6 \%$ were from CSE, ICE, EEE or engineering background areas, $3.1 \%$ from agriculture or agricultural background and the $11.8 \%$ were from other subjects or majors from the various public and private universities from Bangladesh.

Table 4. Year of the study

\begin{tabular}{|c|c|c|c|c|}
\hline & Frequency & Percent & $\begin{array}{c}\text { Valid } \\
\text { Percent }\end{array}$ & $\begin{array}{c}\text { Cumulative } \\
\text { Percent }\end{array}$ \\
\hline 1st Year & 63 & 9.8 & 9.8 & 9.8 \\
2nd & 60 & 9.3 & 9.3 & 19.1 \\
Year & 292 & 45.3 & 45.3 & 64.3 \\
Valid 3rd Year & 214 & 33.2 & 33.2 & 97.5 \\
4th Year & 16 & 2.5 & 2.5 & 100.0 \\
5th Year & 645 & 100.0 & 100.0 & \\
Total & & & & \\
\hline
\end{tabular}

From the table 4 , it was shown that $9.8 \%$ was studying on $1^{\text {st }}$ year, $9.3 \%$ on $2^{\text {nd }}$ year, $45.3 \%$ on $3^{\text {rd }}$ year, $33.2 \%$ on $4^{\text {th }}$ and $2.5 \%$ on $5^{\text {th }}$ year respectively. It was clearly shown that most of the respondents were from the $3^{\text {rd }}$ and $4^{\text {th }}$ year students from the various universities.

Table 5. Region

\begin{tabular}{|c|c|c|c|c|c|}
\hline & & Frequency & Percent & $\begin{array}{c}\text { Valid } \\
\text { Percent }\end{array}$ & $\begin{array}{c}\text { Cumulative } \\
\text { Percent }\end{array}$ \\
\hline \multirow{6}{*}{ Valid } & Dhaka & 189 & 29.3 & 29.3 & 29.3 \\
\hline & Chittagong & 182 & 28.2 & 28.2 & 57.5 \\
\hline & Sylhet & 242 & 37.5 & 37.5 & 95.0 \\
\hline & Rajshahi & 27 & 4.2 & 4.2 & 99.2 \\
\hline & Others & 5 & .8 & .8 & 100.0 \\
\hline & Total & 645 & 100.0 & 100.0 & \\
\hline
\end{tabular}

From the table 5, it was found that in case of region $29.3 \%$ of the total respondents were from Dhaka division,
28.2\% were from Chittagong division, $37.5 \%$ from Sylhet division and $4.2 \%$ from Rajshahi division. And rest of the respondents $0.8 \%$ was from other regions of Bangladesh.

Table 6. Educational Qualification

\begin{tabular}{|c|c|c|c|c|}
\hline & Frequency & Percent & $\begin{array}{c}\text { Valid } \\
\text { Percent }\end{array}$ & $\begin{array}{c}\text { Cumulative } \\
\text { Percent }\end{array}$ \\
\hline BBA & 379 & 58.8 & 58.8 & 58.8 \\
MBA & 8 & 1.2 & 1.2 & 60.0 \\
Vonors \\
$\begin{array}{c}\text { H.A,BS } \\
\text { Salid BSc, }\end{array}$ & 246 & 38.1 & 38.1 & 98.1 \\
$\begin{array}{c}\text { B.Com, } \\
\text { others) } \\
\text { MPhil } \\
\text { And } \\
\text { others } \\
\text { Total }\end{array}$ & 12 & 1.9 & 1.9 & 100.0 \\
\hline
\end{tabular}

From the table 6, it was shown that the percentages of educational qualification of the respondents were as follows, $58.8 \%$ have done BBA degree, $1.2 \%$ had MBA degree, $38.1 \%$ had honors in B.A, BSS, Bsc, B.Com and others. Rest of the $4.3 \%$ had done $M$ Phil and other degrees. That means most of the students were from the undergraduate level of various Bangladeshi public and private universities.

Table 7. University

\begin{tabular}{|c|c|c|c|c|c|}
\hline & & Frequency & Percent & $\begin{array}{c}\text { Valid } \\
\text { Percent }\end{array}$ & $\begin{array}{c}\text { Cumulative } \\
\text { Percent }\end{array}$ \\
\hline \multirow{5}{*}{ Valid } & Public & 294 & 45.6 & 45.6 & 45.6 \\
\hline & Private & 319 & 49.5 & 49.5 & 95.0 \\
\hline & Colleges & 4 & .6 & .6 & 95.7 \\
\hline & Others & 28 & 4.3 & 4.3 & 100.0 \\
\hline & Total & 645 & 100.0 & 100.0 & \\
\hline
\end{tabular}

From the table 7 , we can see that $45.6 \%$ respondents were from public universities, $49.5 \%$ were from private universities, $0.6 \%$ from college levels and $4.3 \%$ were from other institutions. As majority of the educational institutions were private universities.

Table 8. Do you use smartphone/ i-phone?

\begin{tabular}{|c|c|c|c|c|c|}
\hline & & Frequency & Percent & $\begin{array}{c}\text { Valid } \\
\text { Percent }\end{array}$ & $\begin{array}{c}\text { Cumulative } \\
\text { Percent }\end{array}$ \\
\hline \multirow{4}{*}{ Valid } & Yes & 619 & 96.0 & 96.0 & 96.0 \\
\hline & No & 22 & 3.4 & 3.4 & 99.4 \\
\hline & $\begin{array}{c}\text { Not } \\
\text { interested }\end{array}$ & 4 & .6 & .6 & 100.0 \\
\hline & Total & 645 & 100.0 & 100.0 & \\
\hline
\end{tabular}

From the table 8 , it was shown that $96.0 \%$ respondents use smart phones and $3.4 \%$ do not. Another .6\% has shown no interest. The number of smart phone and iPhone users is increasing day by day in Bangladesh.96\% of the 645 respondents from the various private and public universities were using smart phone or iPhone and rest of the $4 \%$ were using any other feature phone. 
Table 9. Do you use computer/laptop/notepad?

\begin{tabular}{|cc|c|c|c|c|}
\hline & Frequency & Percent & $\begin{array}{c}\text { Valid } \\
\text { Percent }\end{array}$ & $\begin{array}{c}\text { Cumulative } \\
\text { Percent }\end{array}$ \\
\hline \multirow{2}{*}{ Valid } & Yes & 556 & 86.2 & 86.2 & 86.2 \\
& $\begin{array}{c}\text { No } \\
\text { interested } \\
\text { Total }\end{array}$ & 81 & 12.6 & 12.6 & 98.8 \\
& 645 & 100.0 & 100.0 & \\
\hline
\end{tabular}

From the table 9, it was found that $86.2 \%$ of the total 645 respondents use computer, laptop or notepad where 12.6 do not. The rest of the $1.2 \%$ is not interested. So the number of computer or laptop or notepad users is the highest in the university levels in Bangladesh.

Table 10. Do you use internet?

\begin{tabular}{|c|c|c|c|c|}
\hline & Frequency & Percent & $\begin{array}{c}\text { Valid } \\
\text { Percent }\end{array}$ & $\begin{array}{c}\text { Cumulative } \\
\text { Percent }\end{array}$ \\
\hline Yes & 637 & 98.8 & 98.8 & 98.8 \\
Volid & 4 & .6 & .6 & 99.4 \\
Not & & .6 & .6 & 100.0 \\
interested & 4 & .6 & 100.0 & \\
\hline
\end{tabular}

From the table 10, it was shown that the $98.8 \%$ of the respondents use internet wherein $.6 \%$ does not. The other $.6 \%$ showed no interest.

Table 11. Which type of Internet connection you use?

\begin{tabular}{|c|c|c|c|c|}
\hline & Frequency & Percent & $\begin{array}{c}\text { Valid } \\
\text { Percent }\end{array}$ & $\begin{array}{c}\text { Cumulative } \\
\text { Percent }\end{array}$ \\
\hline $\begin{array}{c}\text { Mobile } \\
\text { Wifi / } \\
\text { Wimax }\end{array}$ & 245 & 38.0 & 38.0 & 38.0 \\
Valid & 71 & 11.0 & 11.0 & 49.0 \\
Oroadband & 59 & 9.1 & 9.1 & 58.1 \\
One and & 127 & 19.7 & 19.7 & 77.8 \\
All Tyo & 143 & 22.2 & 22.2 & 100.0 \\
Total & 645 & 100.0 & 100.0 & \\
\hline
\end{tabular}

From the table 11, it was shown that type of internet connection they use were as follows- $38.0 \%$ use mobile internet, $11.0 \%$ use wifi or wimax, $9.1 \%$ use broadband. $19.7 \%$ of those respondents use one or two of the above connection type and $22.2 \%$ use all of them.

Table 12. Most of the time, which type of Internet connection you use?

\begin{tabular}{|c|c|c|c|c|}
\hline & Frequency & Percent & $\begin{array}{c}\text { Valid } \\
\text { Percent }\end{array}$ & $\begin{array}{c}\text { Cumulative } \\
\text { Percent }\end{array}$ \\
\hline $\begin{array}{c}\text { Mobile } \\
\text { Wifi / } \\
\text { Wimax }\end{array}$ & 344 & 53.3 & 53.3 & 53.3 \\
Valid $\begin{array}{c}\text { Broadband } \\
\text { One and } \\
\text { Two }\end{array}$ & 72 & 22.2 & 22.2 & 75.5 \\
All types & 39 & 6.0 & 6.0 & 100.0 \\
Total & 645 & 100.0 & 100.0 & 86.7 \\
\hline
\end{tabular}

From the table 12, it was shown that $53.3 \%$ respondents use mobile internet connection mostly and $22.2 \%$ use wifi or wimax, $11.2 \%$ use broadband, $7.3 \%$ use one or two and $6.0 \%$ use all of them most of the time.

Table 13. How much time do you spend on internet in a day?

\begin{tabular}{|c|c|c|c|c|}
\hline & Frequency & Percent & $\begin{array}{c}\text { Valid } \\
\text { Percent }\end{array}$ & $\begin{array}{c}\text { Cumulative } \\
\text { Percent }\end{array}$ \\
\hline $\begin{array}{c}\text { Less than } \\
1 \text { hour to 1 } \\
\text { hour } \\
\text { More than } \\
\text { 1 hour to } \\
\text { less than 2 } \\
\text { hours } \\
\text { More than } \\
\text { 2 hour to } \\
\text { less than 3 } \\
\text { hours } \\
\text { More than } \\
\text { 3 hour to } \\
\text { less than 4 } \\
\text { hours } \\
\text { More than } \\
4 \text { hour to } \\
\text { less than 5 } \\
\text { hours } \\
\text { Total }\end{array}$ & 127 & 18.8 & 7.0 & 7.0 \\
Valid & 92 & 19.7 & 19.7 & 45.4 \\
\hline
\end{tabular}

From the table 13 , it was shown that $7.0 \%$ respondents spend less than one hour on internet every day. $18.8 \%$ use internet for 1 to 2 hours, $19.7 \%$ use it for 2 to 3 hours. $14.3 \%$ of the respondents spend 3 to 4 hours on line and $40.3 \%$ use it for 4 to 5 hours a day.

Table 14. Why do you use Internet?

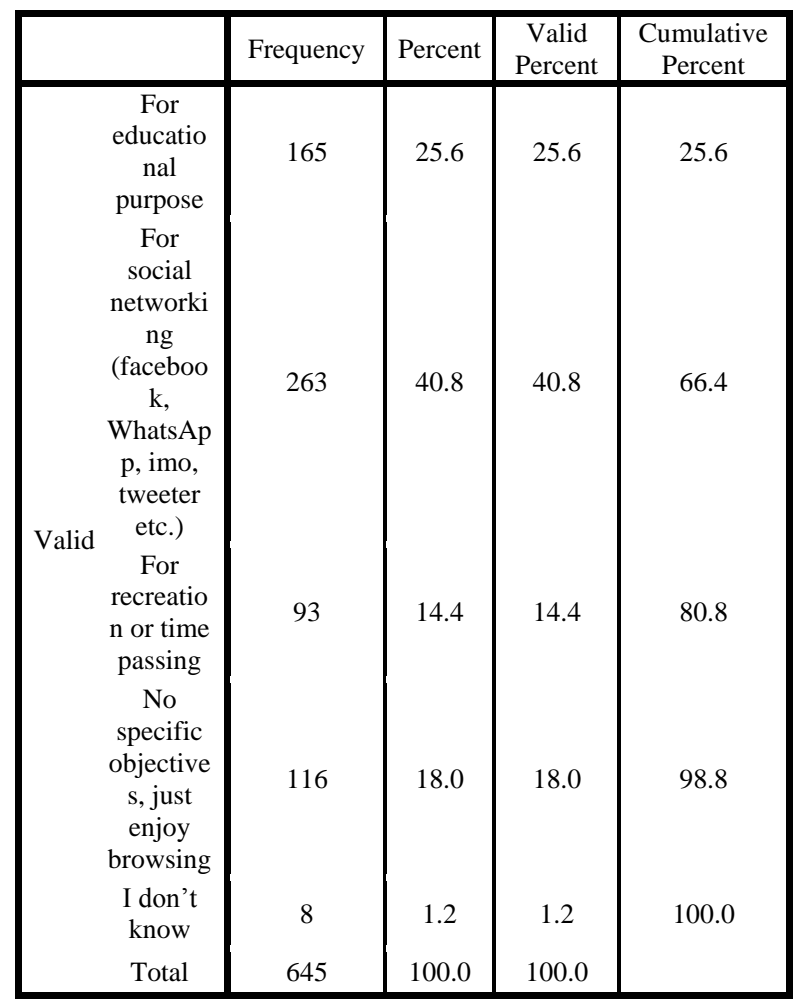


From the table 14 , we can see that $25.6 \%$ respondents use internet for educational purposes, $408 \%$ for social networking, $14.4 \%$ use it for recreation and $18.0 \%$ just enjoys browsing, another $1.2 \%$ has said they don't know why they use it.

Table 15. When are you browsing Internet?

\begin{tabular}{|c|c|c|c|c|}
\hline & Frequency & Percent & $\begin{array}{c}\text { Valid } \\
\text { Percent }\end{array}$ & $\begin{array}{c}\text { Cumulative } \\
\text { Percent }\end{array}$ \\
\hline $\begin{array}{c}\text { When you are in } \\
\text { campus/ } \\
\text { University } \\
\text { When you are in } \\
\text { your residence/ } \\
\text { hall/hostel etc. } \\
\text { When you are in } \\
\text { bus/train } \\
\text { /launch/ air/any } \\
\text { other transportation } \\
\text { When you are in } \\
\text { class room } \\
\text { All of them } \\
\text { Total }\end{array}$ & 33 & 5.1 & 5.1 & 5.1 \\
\hline 2 & 25 & 4.2 & 49.1 & 54.3 \\
\hline
\end{tabular}

From the table 15 , it was found that $5.1 \%$ use internet while they were staying in campus, $49.1 \%$ use it at their residence, $4.2 \%$ use it while travelling and $1.9 \%$ use internet in their class room, $39.7 \%$ have said that they use internet in all of the above places. So it was concluded that the most of the students were using internet when they were staying on their residence or hall or hostel.

Table 16. In which site you spend more time?

\begin{tabular}{|c|c|c|c|c|c|}
\hline & & Frequency & Percent & $\begin{array}{c}\text { Valid } \\
\text { Percent }\end{array}$ & $\begin{array}{c}\text { Cumulative } \\
\text { Percent }\end{array}$ \\
\hline \multirow{6}{*}{ Valid } & Movie & 41 & 6.4 & 6.4 & 6.4 \\
\hline & Games & 36 & 5.6 & 5.6 & 11.9 \\
\hline & Video & 82 & 12.7 & 12.7 & 24.7 \\
\hline & Social & 254 & 39.4 & 39.4 & 64.0 \\
\hline & $\begin{array}{c}\text { All of } \\
\text { them }\end{array}$ & 232 & 36.0 & 36.0 & 100.0 \\
\hline & Total & 645 & 100.0 & 100.0 & \\
\hline
\end{tabular}

From the table 16, it was shown that $6.4 \%$ respondents use internet for browsing movie sites, $11.9 \%$ use it for browsing game sites, $24.7 \%$ for video ,39.4\% use it for social sites and $36.0 \%$ respondents said they use all of them. That means the students of Bangladesh were spending most of his or her valuable time on social networking site. It was clearly stated that they are totally addicted by the social networking sites.
From the table 17 , it was clearly identified that $4.3 \%$ use computer, laptop or notepad for listening to music or watching videos, $14.3 \%$ use them for educational purposes and $70.1 \%$ use them for both reasons. $5.0 \%$ said they use it for other reasons and $6.4 \%$ replied they do not know. So $70.1 \%$ of public and private universities students were addicted by the computer and computer related technology. From the one side it was very alarming and another side it was very potential in nature.

Table 17. Why do you use computer/laptop/notepad etc.?

\begin{tabular}{|c|c|c|c|c|}
\hline & Frequency & Percent & $\begin{array}{c}\text { Valid } \\
\text { Percent }\end{array}$ & $\begin{array}{c}\text { Cumulative } \\
\text { Percent }\end{array}$ \\
\hline $\begin{array}{c}\text { For listing } \\
\text { music and } \\
\text { watching } \\
\text { video } \\
\text { For } \\
\text { educational } \\
\text { purpose } \\
\text { For other } \\
\text { purpose } \\
\text { Valid }\end{array}$ & 28 & 4.3 & 4.3 & 4.3 \\
$\begin{array}{c}\text { Both 1 \& 2 } \\
\text { I don't } \\
\text { know } \\
\text { Total }\end{array}$ & 42 & 14.3 & 14.3 & 18.6 \\
\hline
\end{tabular}


Table 18 . How much time do you spent for your study in a day?

\begin{tabular}{|c|c|c|c|c|c|}
\hline & & Frequency & Percent & Valid Percent & $\begin{array}{c}\text { Cumulative } \\
\text { Percent }\end{array}$ \\
\hline \multirow{7}{*}{ Valid } & Less than 1 hour to 1 hour & 183 & 28.4 & 28.4 & 28.4 \\
\hline & More than 1 hour to less than 2 hours & 207 & 32.1 & 32.1 & 60.5 \\
\hline & More than 2 hour to less than 3 hours & 110 & 17.1 & 17.1 & 77.5 \\
\hline & More than 3 hour to less than 4 hours & 73 & 11.3 & 11.3 & 88.8 \\
\hline & More than 4 hours & 67 & 10.4 & 10.4 & 99.2 \\
\hline & & 5 & .8 & .8 & 100.0 \\
\hline & Total & 645 & 100.0 & 100.0 & \\
\hline
\end{tabular}

From the table 18 it was seen that $28.4 \%$ of the respondents' study for less than 1 hour in a day. $32.1 \%$ said they study for 1 to 2 hours in a day, $17.1 \%$ study for 2 to 3 hours in a day and $11.3 \%$ study for 3 to 4 hours in a day and $10.4 \%$ respondents were studied for more than 4 hours in a day. So it was seen that most of the students of Bangladesh were not attracting on study because they were not spent more than 2 hours in a day.

Table 19. Do you think you spent more time with your smartphone/ iPhone/computer/internet etc.?

\begin{tabular}{|c|c|c|c|c|c|}
\hline & & Frequency & Percent & $\begin{array}{c}\text { Valid } \\
\text { Percent }\end{array}$ & $\begin{array}{c}\text { Cumulative } \\
\text { Percent }\end{array}$ \\
\hline \multirow{6}{*}{ Valid } & $\begin{array}{l}\text { Strongly } \\
\text { agree }\end{array}$ & 244 & 37.8 & 37.8 & 37.8 \\
\hline & Agree & 201 & 31.2 & 31.2 & 69.0 \\
\hline & Neutral & 142 & 22.0 & 22.0 & 91.0 \\
\hline & Disagree & 40 & 6.2 & 6.2 & 97.2 \\
\hline & $\begin{array}{l}\text { Strongly } \\
\text { disagree }\end{array}$ & 18 & 2.8 & 2.8 & 100.0 \\
\hline & Total & 645 & 100.0 & 100.0 & \\
\hline
\end{tabular}

From the table 19 it was shown that $37.8 \%$ strongly agree that they were spending more times on smart phones or internet or iPhone where $31.2 \%$ have agreed upon, $22.0 \%$ were neutral, $6.2 \%$ has disagreed and $2.8 \%$ has strongly disagreed. So it was clearly stated that $69 \%$ of the students in Bangladeshi universities were thinking that they were spending more time on smart phone, iPhone, computer or internet. It is very alarming scenario for Bangladesh if this huge population can't use it properly.

From the table 20 it was found that $64.5 \%$ respondents like social media, $15.0 \%$ like academic sites, $3.7 \%$ like non-academic sites and $4.5 \%$ like gaming sites. $12.2 \%$ have other favorite sites. Among the 645 respondents from various private and public universities 416 (64.5\%) were using social media for their main site and most of the time they use this site for their own purpose.

It was shown that from the figure 1, 406 male and 231 female students were using the internet in Bangladesh among the 645 respondents. It was clearly stated that the rate of male students of internet users were much more than female students in Bangladesh.

In the figure 2 it was shown that 350 male and 206 female students were using computer/laptop/notepad. From the figure 2 it was clearly stated that male students were affecting or addicting more on technology rather than female students.

Table 20. Which is your favorite site?

\begin{tabular}{|c|c|c|c|c|c|}
\hline & & Frequency & Percent & \begin{tabular}{c|} 
Valid \\
Percent
\end{tabular} & $\begin{array}{c}\text { Cumulative } \\
\text { Percent }\end{array}$ \\
\hline \multirow{6}{*}{ Valid } & $\begin{array}{c}\text { Social media } \\
\text { sites } \\
\text { (Facebook, } \\
\text { Twiteer, } \\
\text { WhatsApp, } \\
\text { instragarm } \\
\text { etc) }\end{array}$ & 416 & 64.5 & 64.5 & 64.5 \\
\hline & $\begin{array}{l}\text { Academic } \\
\text { Sites }\end{array}$ & 97 & 15.0 & 15.0 & 79.5 \\
\hline & $\begin{array}{c}\text { Non- } \\
\text { Academic } \\
\text { sites }\end{array}$ & 24 & 3.7 & 3.7 & 83.3 \\
\hline & Gaming sites & 29 & 4.5 & 4.5 & 87.8 \\
\hline & Others & 79 & 12.2 & 12.2 & 100.0 \\
\hline & Total & 645 & 100.0 & 100.0 & \\
\hline
\end{tabular}




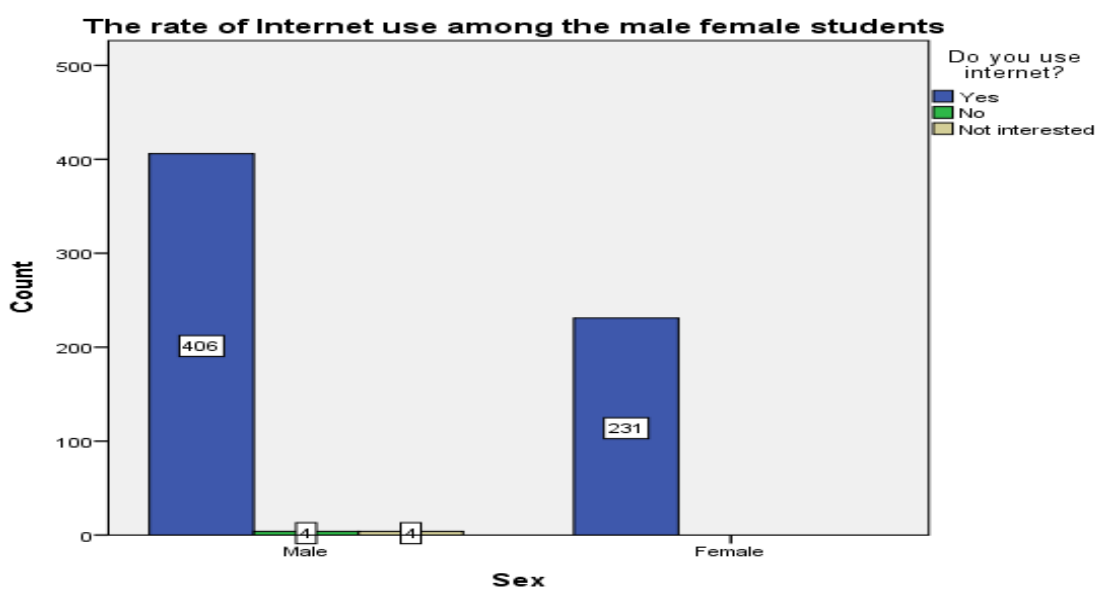

Fig.1. The rate of Internet use among the male and female students

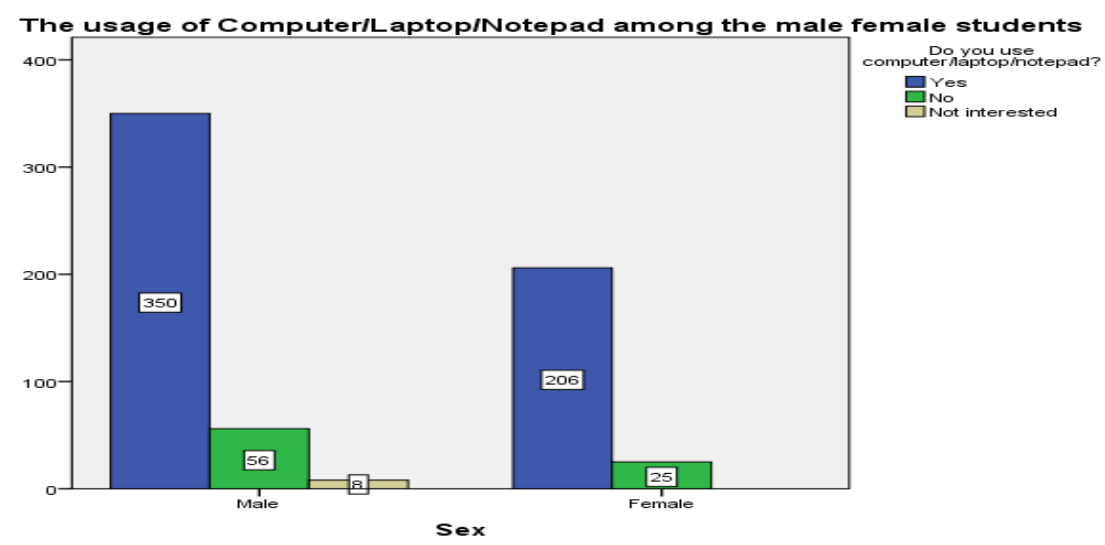

Fig.2. The rate of Computer/Laptop/Notepad use among the male and female university students in Bangladesh.

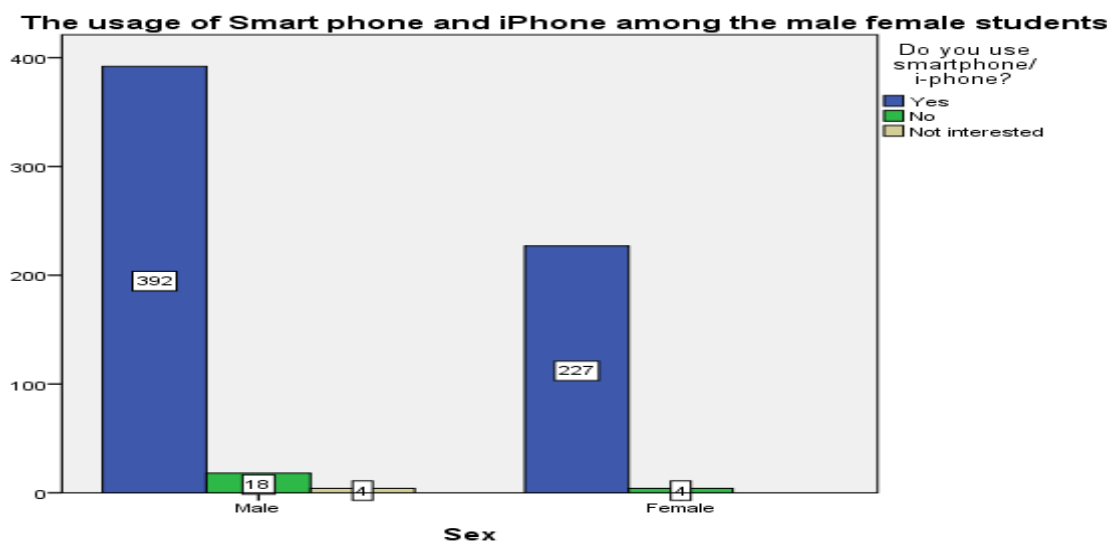

Fig.3. The rate of smart phone and iPhone usage among the male and female university students

From the figure 3 it was shown that among the 645 respondents 392 male and 272 female university students were using smart and iPhone for their daily activities. Though the rate of female respondents were less than the male respondents, the rate of smart and iPhone users are relatively same on this stage. That means the users of smart phone and iPhone are high in the university levels in Bangladesh.

It was shown that from the Figure 4, among the 645 respondents from various private and public universities, 158 male and 102 female students were spending more than 4 hours to less than 5 hours in a day.71 male and 21 female students were spending more than 3 hours to 4 hours on internet in a day, on the other hand 87 male and 40 female students were using internet more than 2 hours to 3 hours in a day. From the above data it was shown that, 73 male and 48 female students were using internet in a day. That means the internet addictions among the university students were affecting the students in all aspects of their life.

It was shown from the figure 5 the rate of internet users from the university students are alarming because at the 
age 21-23 they have been getting addicted with internet and internet related technology. At this age the young generation in our country will be affected by the internet.

From the figure 6 it was shown that the use of computer or laptop or note pad or computer related technology among the young generation is much more than any other generation. The data represented that most of the university student in Bangladesh were using computer or computer related technology in their middle stage of student's life. At the age of 21-23 the university students were getting engaged with computer related technology with full swing.

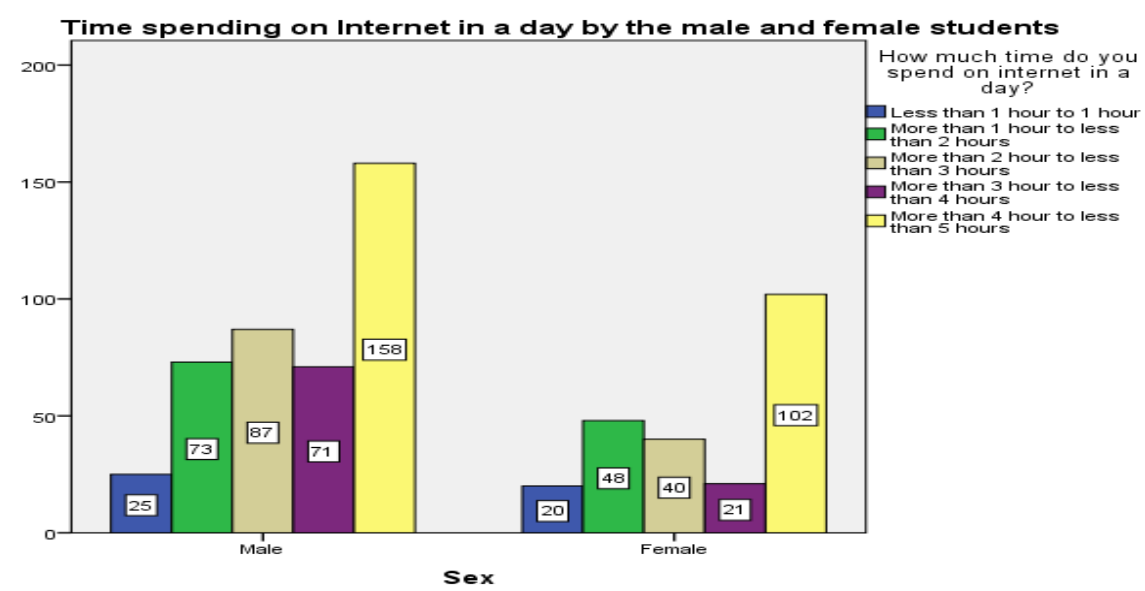

Fig.4. Time spending on Internet by the Bangladeshi university male female student

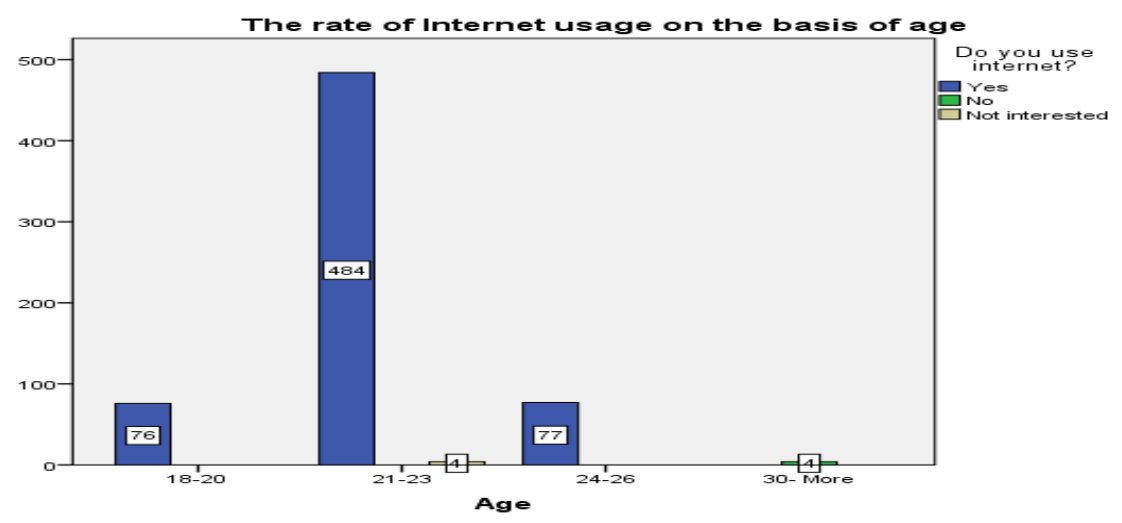

Fig.5. The rate of Internet use on the basis of Age

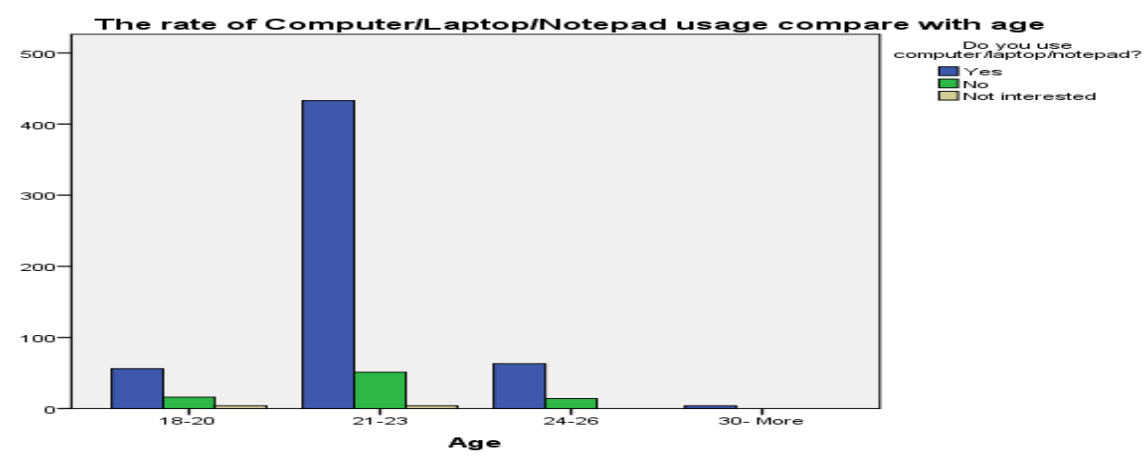

Fig.6. The rate of Computer/Laptop/Notepad usage in comparison with age

From the figure 7 it was shown that the use of smart phone or iPhone or phone related technology among the young generation is higher than any other age group. The data from figure 7 , represented that most of the university student in Bangladesh were using smart phone or iPhone in their middle stage of student's life. At the age of 21-23 the university students were getting affected or addicted by smartphone or iPhone. 


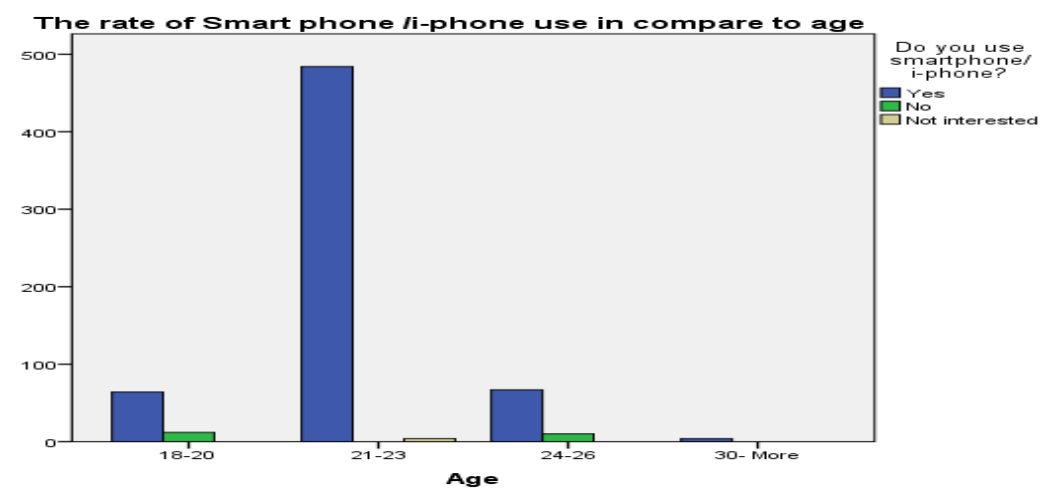

Fig.7. The rate of smart phone or iPhone usage in comparison with age

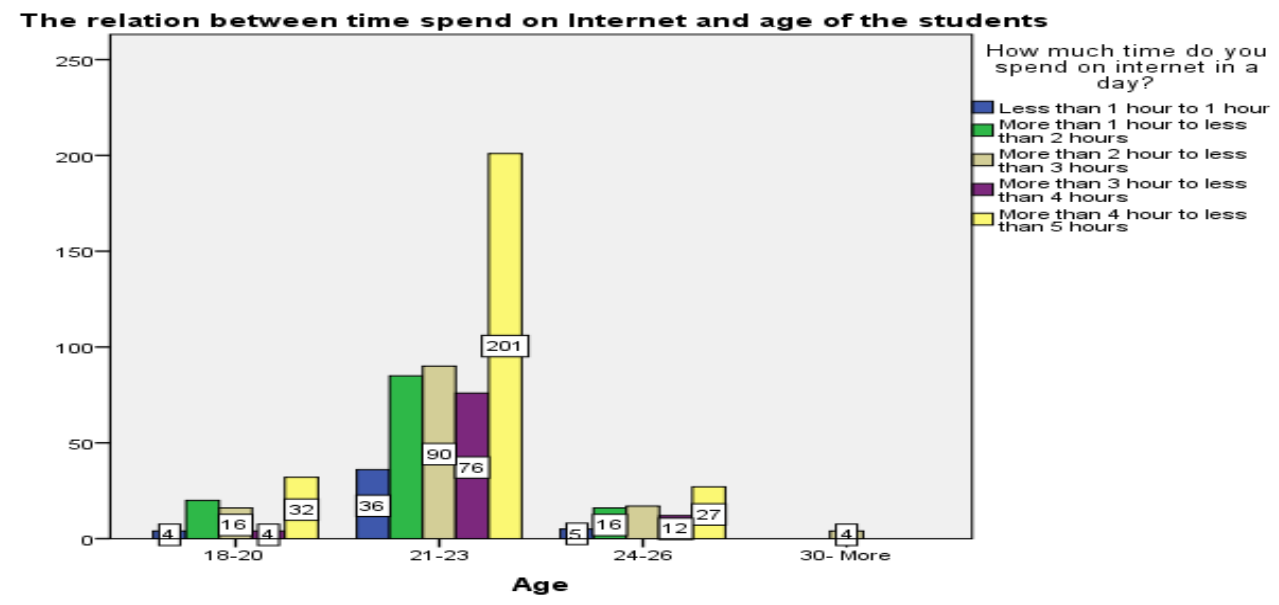

Fig.8. The relationship between time spend on internet and age of the students

The data represented from the figure 8 , it shown that at the age of 21-23 more 201 university students were spending time on internet more than 4 hours to 5 hours in a day.96 students of the same age group spend 3 to 4 hours on internet in a day and 90 students spending 2 to 3 hours on internet in a day. But when they entered into the university life they are not spending more the 1 hour in a day. So the addiction of internet was increasing when they were becoming more adult. It was as clearly concluded that the addiction of internet affecting more at the age of 21-23.

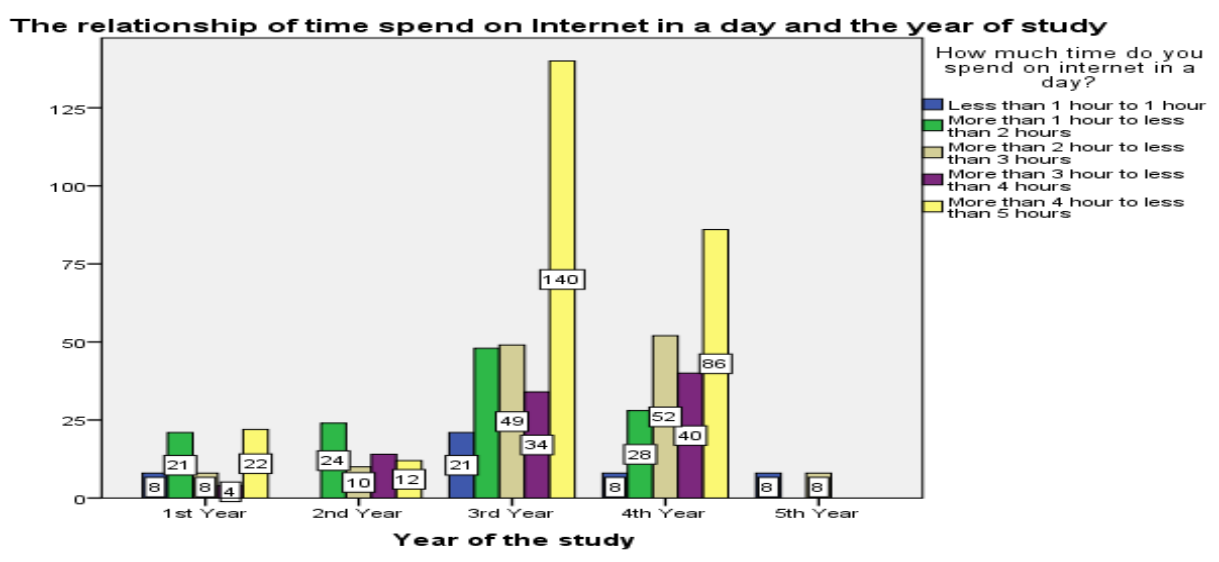

Fig.9. The rate of Internet use on the basis of year of the study

The data represented from the figure 9, it shown that at the year of $3^{\text {rd }}$ and $4^{\text {th }}$ more and university students were spending time on internet more than 4 hours to 5 hours in a day. On the stage of the middle of their study they were getting engaged on internet more than any other stage of their life. So the students of Bangladeshi universities were addicted by the internet on their $3^{\text {rd }}$ and $4^{\text {th }}$ year of their study.

The data presented on the figure 10, it was shown that the internet users among the private and public university 
were equal. Though the rate of internet users are more presented on the figure 10 , because the number of students on private universities are more than public universities. So the internet addiction is equally affected the university students in Bangladesh.

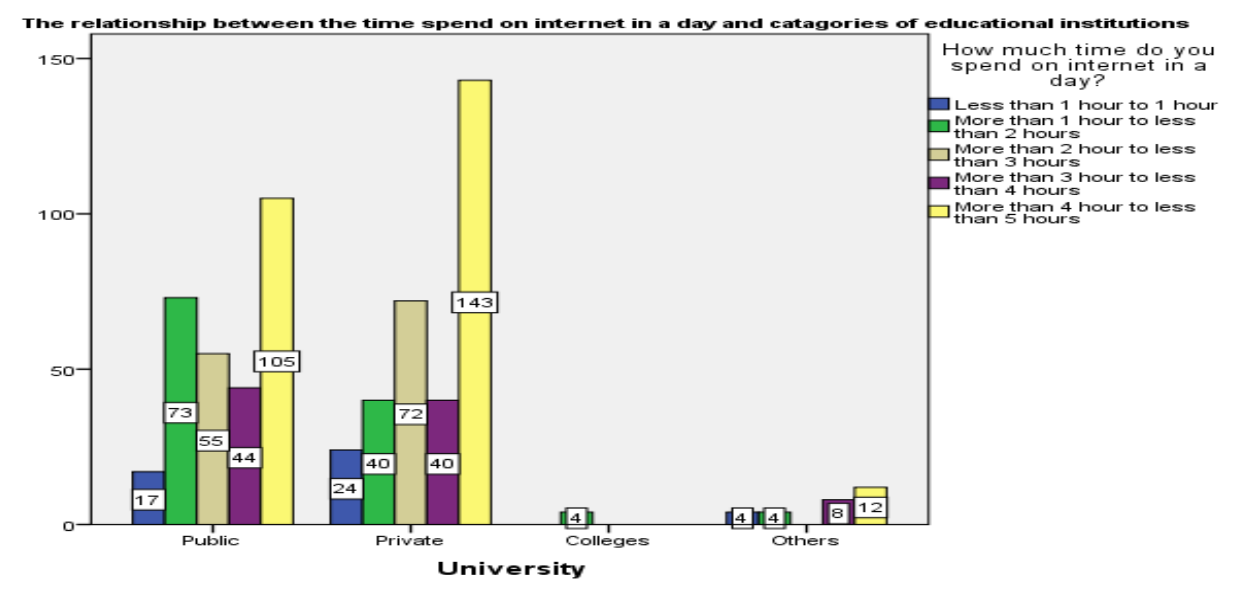

Fig.10. The rate of Internet usage on the basis of University

\section{RECOMMENDATIONS}

There are some findings and recommendations are given below-

All the students from public and private universities are using internet and computer technology for their daily activities. In here there is no discrimination of public and private universities by using modern technologies, from one side it is good sign but from another side it has a great impact on their entire life sometimes it creates dangerous impact.

$>$ The study was identified an alarming fact that most of the $3^{\text {rd }}$ and $4^{\text {th }}$ year students are getting engage on internet and computer technology. But this is the critical moment for the student life in this stage; they can build their potential life from this period of time.

$>$ The addictions of internet and computer technology were being at the age of 21-23 ages among the Bangladeshi university students. These young generations can be an effective nation if they can use their valuable time for potential work. But in Bangladesh the 21-23 2ages' students are totally addicted by the internet and computer technology that's not a good sign for us.

$>$ The rate of smart phone or iPhone use in university level students are increasing day by day most of the smart phone or iPhone users are from the $3^{\text {rd }}$ and $4^{\text {th }}$ year university students. Though they are not engage on smart phone or iPhone from their very begging of student life but at the middle stage they are addicted with smart phone or iPhone by various surrounding environment.

$>$ The young generation and young students have been addicted by computer or laptop or note pad or computer related technology and this addiction have accelerated at the age of 21-23. This addiction can move the students any other way if they can't use it properly.

$>$ Most of the students of public and private universities are spending more than 4 hours in a day that means on an average 28 hours in a week at least. The study was fond that they were spending more time on internet rather than on their study. These 28 hours in a week was very critical for them to use properly. That means the internet addictions among the university students were affecting the students in all aspects of their life.

$>$ Most of the young students are being more addicted with ICT and Internet. They are spending on online rather than off line, in some cases they are totally disconnected from the real world. This alarming situation can only be solved by family and social gathering rather than online or virtual world.

$>$ There is a common trend for the university students that smart phone can become more fashionable for their daily activities. Maximum of the students of university level have smart phone or iPhone at least one, in some case they are using more than one smart phone at a time. The study found that both male and female of students are using smart phone or iPhone for their useful or unusual activities. This addiction can create a serious social crime that is proved in Bangladesh.

$>$ The study was identified a statistical data that the number of male students are being used more internet rather than female students in Bangladesh. So the addiction of internet was more addicted in young male students in Bangladesh.

\section{COMCLUSION}

To analysis all the data which was collected by 
structured questionnaires from various universities in Bangladesh; it was found that the university students were getting engaged with technology and internet at a risky way. Technology was affected the universities students in all aspects though they are not coming for rich family, well-educated family, private universities, public universities and renowned institutions. Technology was arisen as a prime concern in all universities students and they were addicted more and more with this. If we can't introduce the technology or internet among our university students in a proper way, the future of our country would be damaged in systematically and gradually. The future researchers can identify how the university students can involve with this technology and how they can use or even misuse it not only in regional area but also in international area.

\section{ACKNOWLEDGEMENTS}

The researcher wishes to express his gratitude to all the students of various public and private universities in Bangladesh, without their help it was totally impossible for us. The author also expresses special thanks to his wife, Fatema Jannat Juhi, for cordial coordination to make a successful paper indeed.

\section{REFERENCES}

[1] Aristovnik, A. (2012). The impact of ICT on educational performance and its efficiency in selected EU and OECD counteries: A non-parametric analysis. TOJET: The Turkish Online Journal of Educational Technology, 11(3), 144-153. Retrieved from http://www.tandfonline.com/doi/abs/10.1080/03054985.2 011.577938

[2] Art, C. D. (n.d.). Creating digital artwork. Journal of Trauma and Acute Care Surgery, 1-6.

[3] Bahrainian, A., \& Khazaee, A. (2014). Internet Addiction among Students: The Relation of Depression. Bulletin of Environment, Pharmacology and Life Sciences, 3(3), 1-6.

[4] Balfour, R., \& Allen, J. (2014). A Review of the Literature on Sex Workers and Social Exclusion. UCL Institute of Health Equity, (April), 1-23.

[5] Carbonell, X., \& Panova, T. (2017). A critical consideration of social networking sites' addiction potential. Addiction Research and Theory, 25(1), 48-57. https://doi.org/10.1080/16066359.2016.1197915

[6] Casey, B. M. (2012). Linking Psychological Attributes to Smart Phone Addiction, Face-to-Face Communication, Present Absence and Social Capital. International Journal of Mental Health and Addiction, 4(2), 178. https://doi.org/10.3390/ijerph8093528

[7] Claro, M. (n.d.). OECD Background Paper for OECDKERIS Expert Meeting: INFORMATION AND COMMUNICATION TECHNOLOGIES AND EDUCATIONAL PERFORMANCE, 1-18.

[8] Collin, P., Rahilly, K., Richardson, I., \& Third, A. (2011). Literature Review: The Benefits of Social Networking Services, (April), 29. Retrieved from http://www.fya.org.au/wp-content/uploads/2010/07/TheBenefits-of-Social-Networking-Services.pdf

[9] Corporation, A. S. (2003). Tutorial for Authors. Journal of Trauma and Acute Care Surgery, 1-21.

[10] Derevensky, J. L., \& Gilbeau, L. (2015). Adolescent Gambling: Twenty-five Years of Research. Canadian
Journal of Addiction, 6(2), 4-12. Retrieved from http://offcampus.lib.washington.edu/login?url=http://searc h.ebscohost.com/login. aspx?direct=true $\& \mathrm{db}=\mathrm{a} 9 \mathrm{~h} \& \mathrm{AN}=10$ $9985837 \&$ site $=$ ehost-live

[11] Dorji, L. (2015). The Impact of the Internet on Academic Performance of the students at the tertiary level of Education in Bhutan., 53.

[12] Ejechi, E. O. (2016). Information Communication Technology: Are Nigeria's University Students Using It More for Social and Leisure Activities? International Journal of Humanities and Social Science, 6(5), 67-73. Retrieved from http://www.ijhssnet.com/journals/Vol_6_No_5_May_201 6/8.pdf

[13] Eke Miss, H., Omekwu Prof, C. O., \& Odoh Miss, J. N. (2014). The use of social networking Sites among the undergraduate students of University of Nigeria, Nsukka. Library Philosophy and Practice (E-Journal), 1195. https://doi.org/10.5539/ies.v5n3p56

[14] Englander, F., Terregrossa, R. A., \& Wang, Z. (2010). Internet use among college students: Tool or toy? Educational Review, 62(1), 85-96. https://doi.org/10.1080/00131910903519793

[15] Greene, K. M., Approved, T., Praslova, L., \& Georgianna, S. (2016). No Title, (August).

[16] Islam, K. M. R. (2016). Use of Technology in Legal Education of Bangladesh: Challenges and Prospects. Green University, 3(1), 99-116.

[17] Ismail, A. (2016). The impact of information communication and technology on students' academic performance : Evidence from Indonesian EFL classrooms. International Journal of Indonesian Studies, 1(7), 120130.

[18] Jones, T. (2014). Students' cell phone addiction and their opinions. The Elon Journal of Undergraduate Research in Communications, 5(1), 74-80.

[19] Lorencowicz, E., Kocira, S., Uziak, J., \& Tarasińska, J. (2014). Application of ict by students at selected universities in Poland. Turkish Online Journal of Educational Technology, 13(4), 1-11.

[20] Mai, C., \& Wanajak, T. K. (2011). Internet use and its impact on secondary school students in Chiang Mai, Thailand. Edith Cowan University.

[21] Mbah, T. B. (2010). The impact of ICT on students' study habits. Case study: University of Buea, Cameroon. Journal of Science and Technology Education Research, 1(5), 107-110. Retrieved from http://www.academicjournals.org/JSTER

[22] Meenakshi. (2013). Importance of ICT in Healthcare. IOSR Journal of Research \& Method in Education (IOSRJRME), 1(4), 03-08. Retrieved from www.iosrjournals.org

[23] Muduli, J. R. (2013). Addiction to Technological Gadgets and Its Impact on Health and Lifestyle: A Study on College Students. Department of Humanities and Social Sciences National Institute of Technology, Rourkela 769008 India, (412), 46.

[24] Nath, R., Chen, L., Muyingi, H. N., \& Lubega, J. T. (2013). Internet Addiction in Africa: A Study of Namibian and Ugandan College Students. International Journal of Computing and ICT Research, 7(2), 9-22.

[25] Ngoumandjoka, U.-T. (2012). Correlation Between Internet Usage and Academic Performance Among University Students Unnel-Teddy NGOUMANDJOKA.

[26] North, D., Johnston, K., \& Ophoff, J. (2014). The Use of Mobile Phones by South African University Students. Issues in Informing Science and Information ..., 11, 115- 
138. https://doi.org/10.1016/j.tele.2011.11.001

[27] Oduma, C. A. (n.d.). Social Problems of Addicted Use of Information and Communication Technology ( Ict ) Among Undergraduate Students of Nigerian Universities, $5(1), 1-8$.

[28] Omiunu, O. G. (2017). Paradoxical Modeling of the Negative Uses of ICT and their Implications among Secondary School Students in Oyo State, Nigeria. Library Philosophy and Practice (E-Journal)., (June). Retrieved from

http://digitalcommons.unl.edu/cgi/viewcontent.cgi?article $=4200 \&$ context $=$ libphilprac

[29] Opira Geoffrey. (2014). Effects of Information and Communication Technology on Students' Learning: a Case of Gulu University, (1), 1-5. https://doi.org/10.1007/s13398-014-0173-7.2

[30] Rahaman, M. (2017). The Effects of Mobile Phone Use on Human Behaviors: A Study of Developing Country, (November), https://doi.org/10.5815/ijitcs.2017.11.05

[31] Rahaman, M., \& Akter, N. (2017). ICT Used In Education Sector Considering Primary and Secondary Level Schools in Rural Areas : A Study of Sylhet Division in Bangladesh, 19(4), 1-6. https://doi.org/10.9790/487X-1904020106

[32] Schuemann, K. B. (2014). A Phenomenological Study into How Students Experience and Understand the University Presidency, 1-210.

[33] Sussman, S., OMAR, S., BOLONG, J., \& OSMAN, M. (2011). Facebook Addiction Among Female University Students. International Journal of Environmental Research and Public Health, 2(7), 96-109. Retrieved from http://www.uvvg.ro/revad/files/nr7/10. sharifah.pdf and Public Health, 2(7), 96-109. Retrieved from http://www.uvvg.ro/revad/files/nr7/10. sharifah.pdf

[34] Talukder, S., Alam, J., \& Apu, A. I. (n.d.). THE IMPACT OF ICT ON STUDENTS ' PERFORMANCE : A CASE STUDY ON UNDERGRADUATE UNIVERSITY STUDENTS, 137-147.

[35] Teong, K. V., \& Ang, M. C. H. (2016). Internet Use and Addiction among Students in Malaysian Public Universities in East Malaysia: Some Empirical Evidence. Journal of Management Research, 8(2), 31. https://doi.org/10.5296/jmr.v8i2.9092

[36] UNESCO. (2004). Analytical Survey ETHICAL , PSYCHOLOGICAL AND SOCIETAL PROBLEMS OF THE APPLICATION OF ICTs IN EDUCATION

[37] Waithaka, M. W. (2013). Internet Use Among University Students in Kenya: a Case Study of the University of Nairobi, (September), 1-189.

[38] Wang, L. (2011). O nline Game Addiction Among University s Student, 1-48.

[39] Wilkins, L. W. \&. (n.d.). Instructions To Submit a Revised Manuscript, 1.

[40] Yildirim, C. (2014). Exploring the dimensions of nomophobia: Developing and validating a questionnaire using mixed methods research. Graduate Theses and Dissertations. Paper 14005.

[41] Youssef, A., \& Dahmani, M. (2008). The Impact of ICT on Student Performance in Higher Education: Direct Effects, Indirect Effects and Organisational Change. Revista de Universidad Y Sociedad Del Conocimiento, 5(1), 45-56. https://doi.org/10.7238/rusc.v5i1.321

\section{Authors' Profiles}

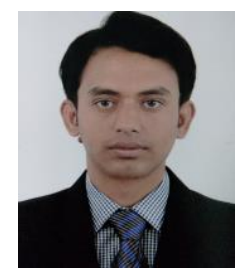

Md. Mahbobor Rahaman was born at a beautiful \& natural city Madhupur under the Tangail district of Dhaka division in Bangladesh. Mr. Md. Mahbobor Rahaman graduated from University of Dhaka, Dhaka Bangladesh. Mr. Md. Mahbobor Rahaman has completed his BBA degree at the year of 2012 \& MBA at the year of 2013 from university of Dhaka in the major field of management information systems (MIS).

He has been serving as a lecturer at Department of Business Administration of Leading University in Sylhet Bangladesh since 2015.He has published more than five articles related to information and communication technology. He is also working as a principle project investigator and co-project investigators in various national critical issues. He has completed a project under the financial support of Leading University, Sylhet, Bangladesh at the year of 2018 .

Mr. Rahaman is interested to work with technology and its impact on various sectors such as ICT for women empowerment ICT for child, ICT for students, ICT for parents, ICT for teachers, ICT for development, sustainable development, economic gap, grass rote level development, remote farmers, ICT for tea workers and ICT for remote areas people's life development etc.

How to cite this paper: Mahbobor Rahaman, "Addiction of Information and Communication Technology (ICT) and Internet by the Bangladeshi University Students and Its Impact on Their Future", International Journal of Information Technology and Computer Science(IJITCS), Vol.10, No.8, pp.56-68, 2018. DOI: 10.5815/ijitcs.2018.08.08 